\title{
スチレン系樹脂
}

斉 藤良*

\section{Styrenic Resin}

Ryo SAITO (Corporate Research \& Development Department PS Japan Corporation, 1-3-1 Yakoh, Kawasaki-Ku, Kawasaki-City Kanagawa 210-0863, Japan)

Polystyrene includes GPPS (General purpose polystyrene) and HIPS (High impact polystyrene). The domestic market of polystyrene was about one million ton/year in 1990' s, but since 2000, the domestic market has been decreasing due to the decrease of electric appliances application. Many electric appliances manufacturers transferred their factories overseas.

Polystyrene manufacturers were reorganized in decade. Ten polystyrene makers of 1993 were gathered to four companies by 2003.

The price of styrene has been soaring since the second half of 2004. Polystyrene is mature business. For general purposes, the number of grades of polystyrene has been decreasing and will continually decreasing in future.

It is not easy to develop new applications or new grades for polystyrene. But, in resent years, a few of new market or polystyrene grades have been developed in fields of optics, food packaging, flame retardation and other functional fields. PS Japan Corporation has various kinds of functional polystyrene grades; low volatile grade, heat resistant grade, transparent HIPS, and so on.

Recycling of polystyrene and safety of styrene oligomer are important.

Also in the future, it is essential to steadily develop new market and original materials of polystyrene.

Key Words : Polystyrene, GPPS, HIPS, Domestic Market, Functional Grade

\section{1. スチレン系樹脂}

スチレン系樹脂と呼ばれる樹脂には, ポリスチレンを始 め $\mathrm{AS}$ 樹脂, $\mathrm{ABS}$ 樹脂, $\mathrm{AES}$ 樹脂, $\mathrm{AAS}$ 樹脂, $\mathrm{ACS}$ 樹脂, さらにはスチレン系エラストマーであるSBSやSEBS等, 多岐にわたる。ポリスチレンにはスチレンのホモポリマー であるGPPSとゴム変性されたHIPS とがある.

本稿ではポリスチレンを中心に，近年の動向と今後の展 望について述べる.

\section{2. 市場 動 向}

ポリスチレンの国内需要の推移を図 1 に示した．国内需 要は，1990年代は 100 万トン前後であったが，2000年以降 減少し，2005年は 86.5 万トンと最低を記録した．2006年 の実績は 87.6 万トンであり，さらに 2007 年，2008年の予 測によれば一応下げ止まりと考えられる.

また，国内需要の推移を見るため，図 2 に 1970 年代か らの年毎の伸び率を示した. 1970 年代には石油ショック 等の影響により伸び率がマイナスになった年もあるが，総
じて高い伸び率である．続く 1980 年代は 1970 年代ほど伸 び率は高くないが安定した伸びを示している，ところが， 1990 年代以降, 伸び率はマイナスの年が目立ち, プラス の場合でも低いレベルとなっている.

1990 年代から 2000 年以降への国内需要の落ち込みの原 因は「電気・工業用」用途が減少したためである。「電 気・工業用」とは家電製品, $\mathrm{AV}$ 電子機器, 記録メディア 類, $\mathrm{OA}$ 機器等である。これら製品が大規模に海外生産移 転したために，ポリスチレンの国内需要が減少した. 2006 年以降は「電気・工業用」用途がやや回復傾向にある。こ れは，薄型テレビ部材向けに拡大しているためと考えられ る. 生産台数もさることながら, 画面の大型化による 1 台

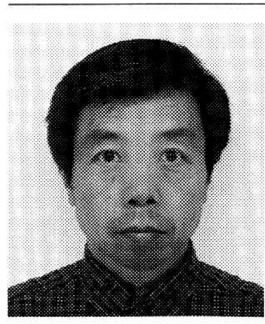

*PS ジャパン(侏研究開発部課長 ( ₹ 210-0863 川崎市川崎区夜光 1-3-1). 昭和 57 年, 東京 大学大学院理学部化学科修士課程卒業. 同年, 三菱化成工業(侏)(現 三菱化学(秼) 入社. 専門は, 高分子化学. 

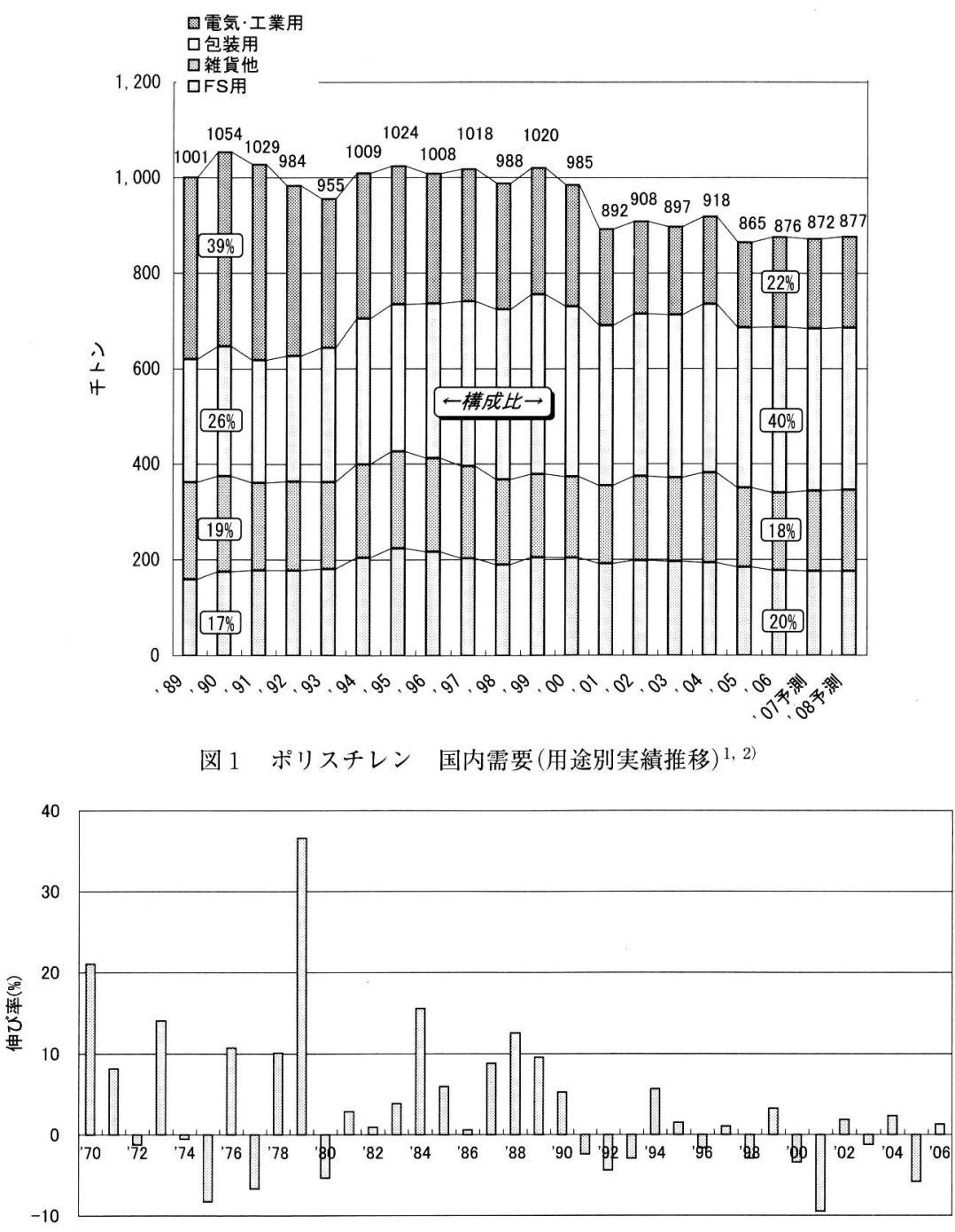

図 2 ポリスチレン国内需要の伸び率(対前年)

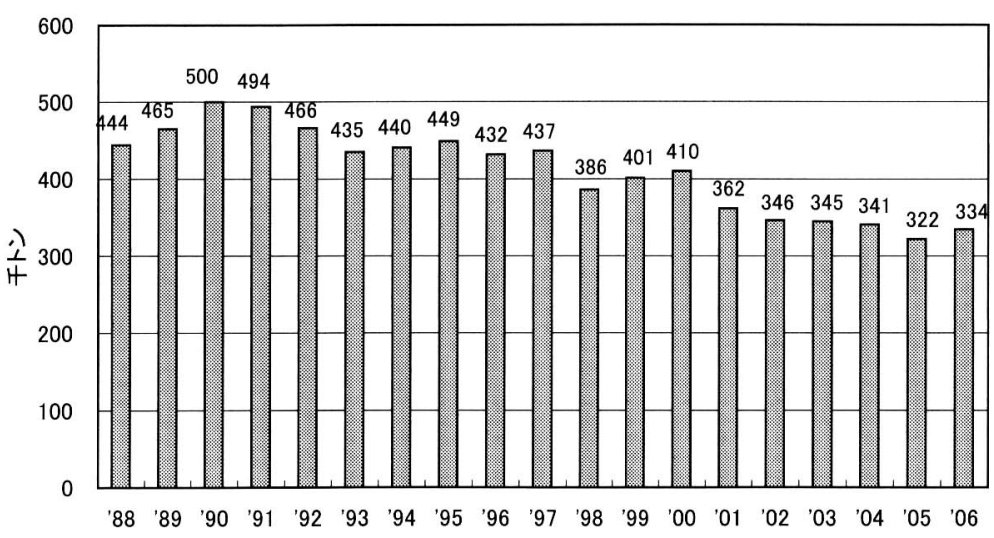

図 3 ABS 国内需要 ${ }^{3}$

あたりの部材使用量の拡大も寄与している.

現在, 日本のポリスチレンは, ほぼ国内需要型となって おり，年間生産量に占める国内需要の割合は約 $97 \%$ に ぶ.アジア各国の新規プラントの稼働や, 国内各社の採算 重視の方針により, 今後も同傾向が続くものと思われる. また，アジア最大の市場である中国では，2004年，2005 年はマイナス成長であり，これ以降も2003年以前のよう
な高度成長は期待できない.したがって, 従来, 中国に輸 出していた韓国, 台湾等のメーカーが日本への輸出を増加 させる可能性があり，国内品はそれら安価な輸入品に対抗 しなければならなくなる。

スチレン系樹脂の中でポリスチレンに次いで国内需要の 高い樹脂は ABS 樹脂である. ABS 樹脂の国内需要の推移 を図 3 に示した。 $\mathrm{ABS}$ 樹脂もポリスチレンと同様に, 


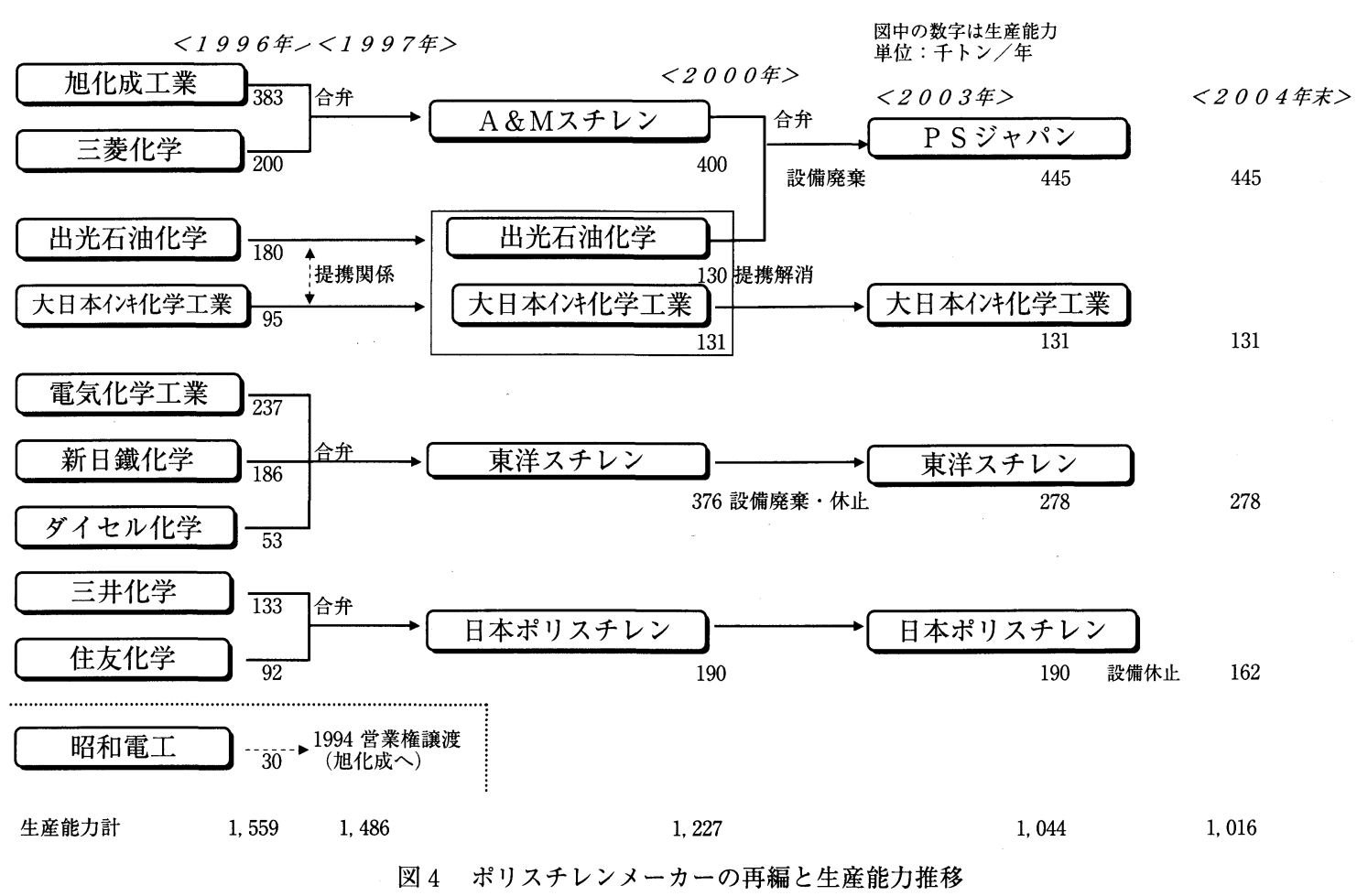

1990 年代以降国内需要が落ち込んでいることがわかる.

\section{3. 業 界 動 向}

ポリスチレンに関しては, 上記のような需要動向を背景 に，ポリスチレンメーカーの再編が活発に行われた. 図 4 にポリスチレンメーカーの再編と生産能力の推移を示し た. 1990 年代前半には 10 社であったポリスチレンメーカ 一の再編が活発に行われ，2003年には，日本ポリスチレ ン侏) (三井化学(侏), 住友化学(侏), 東洋スチレン(秼)(電気化 学工業(侏), 新日鐵化学(侏)，ダイセル化学(株), PSジャパン (侏)(旭化成ケミカルズ(侏), 三菱化学(侏), 出光興産(侏); 以後 $\mathrm{P}$ 社と略す), 大日本インキ化学工業(株)の 4 社体制となっ ている。ささらに，2004年 6 月にはPSジャパン侏と大日本 インキ化学工業侏によるポリスチレン事業の統合が基本合 意されたが，公正取引委員会の承認を得られず，2005年 4 月に基本合意は解消された。今後もさらなる再編・統合の 可能性があると考えられる.

これらの事業再編に伴い，1996年に156万トン／年あっ た設備能力は 2004 年には 102 万トン /年まで減少してい る。それでもなお，需要に対する設備余力が生じており， さらなるスリム化が求められている.

ポリスチレンの原料であるスチレンモノマーは，2004 年後半以降，原油高騰に伴い大幅に価格が上昇している. スチレンモノマーの価格上昇により，ポリスチレンと $\mathrm{ABS}$ 樹脂との值差が相対的に小さくなるという現象が生 じている，早期の原油価格低下および安定化が望まれる。
4. 技術動 向

ポリスチレンは無色透明の沉用ポリスチレン (GPPS) と， その短所を改良した耐衝撃性ポリスチレン (HIPS) とに大 別される. GPPSは，ガラスとほほ同等の可視光線透過率 を持つ無色透明樹脂で，強度はあるが耐衝撃性は比較的低 く脆い. 成形時の熱安定性，流動性に優れ，したがって成 形加工が容易で寸法精度も良い。また，耐油性は良くない が, 酸, アルカリに安定で, 比重も軽く着色性に優れる.

一方，HIPSは，ポリスチレンの海にゴム粒子が分散し ている構造を持った乳白色不透明の樹脂で，剛性はGPPS に劣るものの耐衝撃性は大幅に改良されている.

ポリスチレン事業は，メーカー再編に伴いグレード統合 が進められてきた。一般用途においては，さらなる標準グ レード化が進むものと思われる，各社とも，GPPSでは用 途に合わせて分子量，すなわち流動性を変えた数多くのグ レードがあったままたＨIPSではマトリックスであるポ リスチレンの分子量の他に，ゴム種㧍よびゴム量を種々変 えることにより多数のグレード構成を作っていた．製造合 理化・コストダウンのため, 極力, これらのグレード数を 減らすことが現在進められている.

一方, 前述のように日本国内の既存需要は伸び悩んでお り，大きな需要が見达まれる新たな分野の開拓は簡単では なく, 地道な用途開発, 材料開発, 品質改良が続けられて いる. 以下に，新規な用途および材料について述べる.

\section{1 光学用途}

液晶テレビの拡散板においては, 従来アクリル樹脂 (PMMA) が使用されてきたが，当該樹脂は吸水率が高い 
ため，特に大型サイズの機種で板が反るという問題があっ た。そこで，吸水率がアクリル樹脂より低いスチレンーメ タクリル酸メチル共重合体(MS樹脂)が採用された．加え て，最近ではさらに低吸水でコスト有利なポリスチレン (GPPS) に変更されるようになっている，今後は各種ディ スプレーパネルおよび導光板等への展開が期待される.

\section{2 食品容器用途}

乳等省令規格によれば，ポリスチレンは乳酸菌飲料に直 接接することができる数少ない樹脂のひとつである．飲料 に直接接することから，ポリスチレン中のスチレンモノマ 一等の揮発性成分が少ないことが採用の条件とされる，P 社は揮発性成分を大幅に削減したインジェクションブロー グレードを上市している。

電子レンジで加熱する場合, 容器が通常のポリスチレン では熱による変形が起こる場合が少なくない。これに対し て，P社はコポリマー化によってGPPSの耐熱性(ビカッ 卜軟化温度)を約 $20{ }^{\circ} \mathrm{C}$ 向上させた．電子レンジ対応の発泡 容器として展開されている.

\section{3 難燃グレード}

ポリスチレンの難燃グレードは現在でもハロゲン系(ノ ンデカブロ)が主流となっている，ノンハロゲン系として はリン酸エステル類を用いた系が開発されているが，コス トパフォーマンスがハロゲン系には及ばない。ポリスチレ ンは比較的燃えやすい樹脂であることもあり,ハロゲン系， リン酸エステル系以外で，難燃性に優れた系はほとんど見 出されていないようである．現行難燃剤の配合量を減らす ことによるコストダウン，あるいはポリスチレンに適した 新規の難燃剤を求めて地道な努力が続けられている.

\section{4 透明HIPS}

通常のゴム変性ポリスチレン (HIPS) は不透明であるが， コポリマー化によりゴム成分と屈折率を合わせることによ り透明化できる，P社では, 食品容器, トレー, キャリア
テープ, マガジンレール等の電子包材, 低温収縮フィルム, その他意匠性のある射出成形材料等に使用している.

\section{5 その他の機能性グレード}

上記以外のポリスチレン系の機能性グレードとしては, 耐薬品グレード，摺動グレード，持続制電グレード等が挙 げられる。

\section{5. 環境対応, 安全性}

\section{1 リサイクル，有効利用}

容器包装リサイクル法や家電リサイクル法の施行によっ て，各種製品のリサイクルが行われるようになり，資源の 再活性が図られるようになってきた，廃プラスチックの有 効利用率は 1996 年頃から上昇して 2005 年には $62 \%$ に達し た(表 1 ).ただし，2005年の有効利用量 628 万トンの内， 再生利用は 185 万トンにとどまっている(表 2 ). 樹脂別に 見ると，2005年のポリスチレン類 (AS, ABSを含む)の再 生利用率は $17.5 \%$ \%゙あり，ポリエチレンやポリプロピレ ンの再生利用率よりも高いが塩化ビニル樹脂より低い值と なっている (表 3 ). 今後も, 廃プラスチックの再生利用を 始めとして，更なる有効利用の向上が望まれる.

\section{2 使用量低減, 環境維持}

加工メーカーでは薄肉化, 軽量化により使用量を削減す る動きも活発である。このことは, 樹脂メーカーにとって は需要量の低下を意味し一見好ましくないように思える. 実際, 近年は容器の軽量化がPSP (ポリスチレンペーパー) における減少要因となっている.

一方，近年，ポリ乳酸に代表される植物由来樹脂が非常 に注目を集めている，石油資源の枯渴，二酸化炭素による 地球温暖化が指摘される中で, 石油資源を使わない, 二酸 化炭素を増加させない植物由来樹脂を使いこなすことが精 力的に検討されている. ポリスチレンを始め石油由来樹脂 にとっては喎威になりつつある. 石油樹脂メーカーとして

表 1 廃プラスチックの有効利用量と有効利用率の推移

\begin{tabular}{c|c|c|c|c|c|c|c|c|c|c|c|c|c}
\hline 年 & 1990 & & 1995 & 1996 & 1997 & 1998 & 1999 & 2000 & 2001 & 2002 & 2003 & 2004 & 2005 \\
\hline 廃プラ排出量 万 $\mathrm{t}$ & 557 & & 884 & 909 & 949 & 984 & 976 & 997 & 1016 & 990 & 1001 & 1013 & 1006 \\
\hline 有効利用量 万 $\mathrm{t}$ & 144 & & 221 & 358 & 399 & 435 & 452 & 494 & 535 & 542 & 575 & 611 & 628 \\
\hline 有効利用率 \% & 26 & & 25 & 39 & 42 & 44 & 46 & 50 & 53 & 55 & 58 & 60 & 62 \\
\hline
\end{tabular}

表 2 廃プラスチック処理方法内訳(2005年)

\begin{tabular}{|c|c|c|c|c|c|c|c|c|}
\hline 処理方法 & 再生利用 & 油化/ガス化/高炬原料化 & 固形燃料 & 廃棄物発電 & 熱利用燒却 & 単純焼却 & 埋立 & (計) \\
\hline 量/万t $(\%)$ & $185(18.4)$ & $29(2.9)$ & $62(6.2)$ & $231(23.0)$ & $121(12.0)$ & $123(12.2)$ & $255(25.3)$ & $(100)$ \\
\hline & \multicolumn{5}{|c|}{ 有効利用 計 628 万 $t$} & & & \\
\hline
\end{tabular}

表 3 樹脂別排出量と再生利用量 (2005年) ${ }^{4}$

\begin{tabular}{l|c|c|c|c|c|c}
\hline \multicolumn{1}{c|}{ 樹脂別 } & ポリエチレン & ポリプロピレン & ポリスチレン類 & 塩化ビニル樹脂 & その他 & (計) \\
\hline 排出量/万 $\mathrm{t}$ & 335 & 223 & 154 & 102 & 192 & 1006 \\
\hline 再生利用量/万t & 36 & 28 & 27 & 23 & 71 & 185 \\
\hline 再生利用率/\% & 10.7 & 12.6 & 17.5 & 22.5 & 37.0 & 100 \\
\hline
\end{tabular}


も環境維持に配慮した材料, たとえば薄肉, 軽量化に適し た材料等の開発が必要であろう.

\section{3 安全性}

EUの RoHS 指令 (製品中の有害物質の使用を禁止する指 令) が2006年 7 月に施行された。一時, ハロゲン系難燃剤 が全面使用禁止というドラフト案もあったが，最終的には デカブロ(デカブロモジフェニルエーテル)も含むほとんど のハロゲン系難燃剤が対象から外れ, 通常の臭素系難燃剤 を使用することは当面問題なくなった．とは言うものの， 樹脂メーカーは引き続きコストパフォーマンスの高いノン ハロゲン難燃材料の開発に取り組んでいかなければならな w.

\section{4 スチレンオリゴマーの安全性}

ポリカーボネートの原料であるビスフェノール A が内 分泌摚乱物質いわゆる環境ホルモンの疑いがあるとして大 きな議論になったことは記憶に新しい. ポリスチレン中に 含まれるスチレンダイマーおよびスチレントリマーも「内 分泌擋乱作用を有すると疑われる化学物質 (1997年 7 月外 因性内分泌擋乱化学物質問題に関する研究班中間報告)」 としてリストアップされたことがある. しかしながら，そ の後実験結果等が吟味され，2000年 10 月には環境庁より 追加修正見解が報告され，スチレンダイマー・トリマーは 「環境ホルモンの疑いがある物質」のリストから削除され ている.

\section{6. 今後の課題, 取り組み}

ポリスチレンの国内市場は成熟しており，新たな大きな 市場を見出すことは簡単ではない. また，ここしばらく続 いている石油化学原料の価格高騰も足かせになっている.

ポリスチレンはスケールの大きい連続重合装置にて製造 したものをそのまま供給するというのが基本的なスタイル となっており，加工費を安く抑えることができる反面，多 種多様なニーズには対応しがたい面がある．コンパウンド 等により，少量多品種に対応することはできるが，コスト アップになってしまう。材料開発を行うにあたり, 現行製 造設備でいかに差別化したグレードを製造できるか，ある いはコンパウンド等によるコストアップに対して, どれだ
けの付加価值のある材料を作り出せるかがポイントとな る.

新規市場の獲得方法のひとつとして上位樹脂からポリス チレンへの切り替えが考えられる，前述したように，液晶 テレビ等の拡散板がアクリル樹脂から最終的にGPPSに替 わりつつあるのは, ポリスチレンが安価であるのみならず, 吸水による反りが少ないためであった。このような，ポリ スチレンの特質を生かした用途を見出していくことが重要 である。

一方，ポリスチレンの欠点の改良も必要である，GPPS は透明であるので，同じく透明であるアクリル樹脂やポリ カーボネートを代替できる可能性があるものの, GPPSは, アクリル樹脂に比べて耐候性や表面硬度に劣り，ポリカー ボネートに比べて耐衝撃性や耐熱性に劣っている。これら 欠点の全てではなくともある程度克服することができれ ば，用途によりポリスチレンへの変更は可能となる，たと えば，ポリスチレンがほとんど使用されていない自動車分 野への道も開けると思われる。

今後も，ポリスチレンの新規市場の探索および新規材料 の開発を地道に行っていくことが不可欠であることは言う までもない。

\section{References}

1) Nippon Styrene Kougyoukai Ed.: "Polystyrene Seisan Syukka Jisseki", Nippon Styrene Kougyoukai, Tokyo (2006)

2 ) Nippon Styrene Kougyoukai Ed.: "PS Zyuyou Nippon Asia no Tyuki Tenbou", Nippon Styrene Kougyoukai, Tokyo (2006)

3 ) Nippon ABS Zyushi Kougyoukai Ed.: "ABS Zyushi Seisan Syukka Zisseki", Nippon ABS Zyushi Kougyoukai, Tokyo (2006)

4) Plastic Syori Sokushin Kyoukai Ed.: "Plastic no Seisanryou to Haisyutsuryou no Suii", Plastic Syori Sokushin Kyoukai (2005)

\section{日本語表記参考文献}

1) 日本スチレン工業会編：ポリスチレン生産出荷実績，日本スチ レン工業会, 東京 $(2006)$

2 ) 日本スチレン工業会編：PS需要・日本・アジアの中期展望, 日 本スチレン工業会, 東京 (2006)

3 ）日本 $\mathrm{ABS}$ 樹脂工業会編： $\mathrm{ABS}$ 樹脂生産出荷実績, 日本 $\mathrm{ABS}$ 樹 脂工業会, 東京 (2006)

4 ）プラスチック処理促進協会編：プラスチックの生産量と排出量 の推移，プラスチック処理促進協会，東京 (2005) 